\title{
A Collaboration Between Linguistics and Genetics: Tracing the Bajo Diaspora History in Eastern Indonesia
}

\author{
Philippe Grangé \\ Université de La Rochelle, France \\ pgrange@univ-lr.fr
}

\begin{abstract}
This paper aims at comparing and discussing recent findings from human genetics (genomics) and linguistics, regarding the long-lasting question of the Sama-Bajau / Bajo diaspora in Eastern Indonesia, Sulu archipelago (South Philippines) and Sabah (Malaysia). The Bajo are a maritimeoriented people, and some of them were sea nomads until the 1970s. They scattered over this wide zone centuries ago, they forgot their territory of origin, and the original Sama-Bajau language locally diversified in a dozen of languages or dialects. If we consider the common patterns of their origin myths, it seems that they were forced to flee their homeland by a foreign power. Genomics shows early admixtures with the Bugis (South Sulawesi) and the dating of their diaspora broadly matches with the linguistic data. The unidentified political event that drove them out their homeland probably happened at the end of the $11^{\text {th }}$ century. If genetics and linguistics data correspond, these data are strongly backed. However, we came upon a serious discrepancy about the location of the Sama-Bajau homeland: geneticists assert it was South Sulawesi, while linguists believe it was South Kalimantan, because SB languages are related to South Barito cluster more than to any other language in Southeast Asia.
\end{abstract}

Keywords - Sama-Bajau; Bajo; Sama-Bajau language; sea nomads; maritime diaspora; Bugis; Sulu Archipelago

\section{INTRODUCTION}

The Bajo (Sama-Bajau) people are nowadays dispersed in dozens of villages on the coast of eastern Indonesia, southern Philippines (Sulu archipelago) and Sabah (Malaysia). In Indonesia, they call themselves 'Sama' [samə] or use the exonym 'Bajo', which is not considered offensive (as it may be in the Philippines). The Sama-Bajau language family, which includes a dozen of languages, clearly shows that the communities, scattered thousands of nautical miles away from each other, all came from one and only place of origin. However, the memory of the Sama-Bajau's homeland has been totally forgotten because their migrations began well before the colonial period and took place in stages. To my knowledge, the Bajo are not mentioned in any old Javanese or Malay text and the first known reference to this ethnic group is a brief jotting written by the Portuguese merchant Tomé Pirès [1] in Malacca around 1515.

The question of their origin intrigues and fascinates the Sama-Bajau themselves: unlike other peoples oriented towards maritime activities, and great seamen like the Bugis, the Sama-Bajau cannot refer to any territory of origin, not even to a city or a symbolic monument. Since their ongoing diaspora did not leave any archaeological evidence, only linguistics and genetics can contribute to tracing this migration, back to their homeland. The Sama-Bajau oral tradition evokes various territories of origin, notably in Peninsular Malaysia, but in the absence of historical data, is there any scientific argument to support these traditional origin accounts ?

This paper aims at comparing recent findings from human genetics (genomics) and linguistics, two science fields which collaborate more and more. Focusing on Sama-Bajau people, I will deal with genomics data (resulting from a joint research with geneticists from the University of Toulouse and Eijkman Institute in Jakarta) and linguistic data from various scholars, including my field work in many Bajo villages in Eastern Indonesia. The main issue of this paper is to find out if through a transdisciplinary approach (genomics and linguistics) we can understand the stages of this migration and point to the Sama-Bajau territory of origin.

The first section reviews the Bajo oral traditions about their origin. There are some common features in almost all of their myths of origin, but they point to different places, depending on which Bajo community we consider.

The second section examines and summarizes genomic findings, quoting Kusuma et al. (2017) [2]. They exclude various possibilities regarding the original location of the Bajo ethnic group, so that we can now "zoom" on a particular region of Insular Southeast Asia.

The third section deals with the linguistic data, arguing that the Indonesian Bajo did not migrate southwards from South Philippines (as is assumed in the existent literature). Indeed, from the starting point of their dispersion, the SamaBajau exiles found refuge in two distinct zones

Lastly, we will examine if the findings from genomics and linguistics do match or not, and whether this transdisciplinary approach can provide a convincing clue about the very first Sama-Bajau homeland. 


\section{SAMA-BAJAU ORAL TRADITIONS ABOUT THE ORIGIN OF THEIR ETHNIC GROUP}

\section{A. The Lost Princess : a set of origin myths}

A famous Sama-Bajau origin myth, on which I put the generic label "the lost Princess", is commonly mentioned by scholars who have studied the Sama-Bajau people, whatever their scientific field. However, before sketching this myth, two features must be underlined. Firstly, there are many different versions of this myth; while the main character is always a lady who travels by sea, she is not necessarily identified as a princess, and she is not always lost. Secondly, this myth or set of myth variants is often presented as a common denominator among all the Sama-Bajau communities over their present diaspora zone. I think this is a bias, because a huge part of the ethnographic surveys have been completed in South Philippines, esp. the Sulu (before the current violent unrest), to a lesser extent in Sabah (Malaysia), but very few in Indonesia (see for instance Lapian [3], Zacot [4], Nagatsu [5], Stacey [6] and Nuraini [7]). The "lost Princess" myth is by no means universal within the Sama-Bajau communities.

This myth includes a 'main stream' variant, in which the Princess is the daughter of Johor Sultan. This account claims that the Bajo people were driven out of Johor (now a state of peninsular Malaysia) either because they had failed to prevent an attack on a ship carrying their princess, or because they had themselves carried out the attack, or alternately because they had failed to find the princess after being sent to search for her. Sather [8] quotes a version recorded on the east coast of Kalimantan (Borneo) in 1849 : "The Bajau came originally from Johor. Once a Johor princess disappeared during a storm at sea. The Sultan of Johor organized a group of people to search for her. However, the lost princess could not be found, and the people who were looking for her found themselves far away from Johor and were unable to find their way back again, and so they settled down along the coastal areas of Borneo, Sulawesi and in the Sulu Archipelago". In another version, the Bajo sailors had not lost their way but never returned to Johore for fear of being punished for having failed. Liebner [9, 10] gives a precise account of some "Princess adrift: Bajau origin stories" variants. Of course, none of these stories mention any date or any identifiable historical event that we could refer to.

Amazingly, because this myth is mentioned again and again in diverse reports, paper, books about the Sama-Bajau, it has almost acquired a force of law. For instance, today most inhabitants of the Malaysian province of Sabah in North Borneo are convinced that the Sama-Bajau did indeed originate in the Sultanate of Johor. The fact is that authors of school textbooks appear to have relied on the authority of some respected scholars to confirm this geographical origin. Nagatsu [5] quotes a high school textbook of Malaysian history published in 1981, which states that the Bajau "are Muslims and immigrant nations to Sabah. They came from Johor during the Sultanate of Brunei era. They are regarded as bumiputera just as the Brunei Malay are. [...] The Brunei and the Bajau people seem to be a similar kind of the Peninsular Malay people." This account of the Sabah Sama-Bajau origins conveniently confers legitimacy upon the claim that the Bajau are part of the Malaysian nation, for the State of Johor is in peninsular Malaysia, relatively close to the capital of this country, see [7].

However, the Johor origin hypothesis is not convincing for several reasons. Not a single Bajo community is to be found in peninsular Malaysia today. The only thing the "sea peoples" (Orang laut) of Riau province, offshore from Sumatra, have in common with the Sama-Bajau is a similar way of life but their languages are not related [11]. The SB languages have lexical similarities with Malay, but these are either cognates (from Proto-Malayo-Polynesian) or loanwords from Malay (or nowadays from Indonesian/Malaysian). If the Bajos had originally come from Johor, why is there not even the smallest group of them left there? Why is there not a single Bajo village in western Indonesia, while they settled so successfully in many spots over the eastern part of this wide archipelago? Furthermore there is no trace in the history of Johor of any coastal dwelling people having been expelled or banished. As a matter of fact, the Johor Sultanate was founded after the conquest of Malacca by the Portuguese in 1511. More than four centuries before, the Bajo had moved from their mysterious homeland, and they were probably already scattered all along the Makassar Strait and the Sulu archipelago when Johor Sultanate arose. The beautiful myth of the "Bajo Princess from Johor" is historically impossible.

Moreover, the "out of Johor" claim was unheard of by my Bajo informants in the southern part of Indonesia, around Makassar Strait and Flores Sea (except to those who have read Lapian's book). Some of them in Eastern Lesser Sunda Islands actually have a narrative of their origins that is relatively similar to the story of the Johor princess: in olden times some Bajos were wandering in search of a lost sister, whom they could not find because she was hiding in the bamboos of their boat; they never returned for fear of punishment. But no particular place of origin is brought up.

Another variant, in Southeast Sulawesi and other villages around Flores Sea, says that a drifting bamboo went close to a boat, although the seamen had repelled it twice; at the third time, they decided to take it on board. Later, a beautiful lady came out of this bamboo. Other versions just tell that she travelled in a small perahu and landed alone on a shore. Then the king (seemingly Bugis or Goa) felt in love with her, and married her, although she did not utter a single word. Months later, the king heard her singing to her baby in Bajo language, thus uncovered her origin; this legend does not make clear why this Bajo women had to flee, and why she wanted to hide her identity.

Other origin myths do not mention any lost princess. In Sulu, a myth noted by Nimmo [12] explains that the Bajo used to live somewhere near Peninsular Malaysia. One evening, they tied their boats to a big black pillar in the middle of the sea. But it was the tail of a giant skate fish, which at night started to swim and towed all the boats very far, far away, eastwards, until the Sulu archipelago, where the Bajo eventually settled. In Southeast Sulawesi, the story is totally different: a huge tree was cut and felt by a hero to make a big perahu (dugout pirogue); the tree had thousands of bird nests on its branches, and when it fell, all the eggs broke, and the 
egg yolks formed a big wave, a kind of tsunami which dispersed the Bajo seamen all over the Flores sea. This is obviously an elaboration on an episode of the Bugis literary masterpiece I La Galigo: the hero Sawérigading fells down the holy tree Wulenreng (or Wélenréng), but nothing is written about an egg yolk wave and a subsequent Bajo dispersion at sea.

It makes sense that the Bajo, anxious to know and to tell where is their homeland, and maybe frustrated for being considered as people "from nowhere", borrowed some myths or particular elements from their closest neighbours mythology. This is also the case of the "princess breaking out of a drifting bamboo" variant, recalling the myth of "the princess born from a bamboo", famous in Kutai-Paser area (East Kalimantan).

Beyond the irreconcilable diversity of these myths, reference to local powerful states is an essential feature. Obviously, the unknown event that triggered the Sama-Bajau diaspora also destroyed most of their political system. Without a centralized power, without an army, they had not choice but to befriend the powerful rulers around them, and provide commodities and services in exchange for staying permit (on the shores) and security... As noted by Hoogervorst [13] (p. 252) : «[...] several Sama-Bajau groups claim descent from the Malay kingdom Johor in the Strait of Malacca. Such claims must be contextualised in a setting of semimythological lineages from and patron-client relations with ruling dynasties [...] ». Another variant quoted by Liebner [10] recounts that the Brunei dynasty had a Bajo male ancestor. The same principle applies to the Indonesian Bajo people around South Sulawesi: there was no point in claimig legitimacy from a state as far as Johor or Brunei. The powerful kingdoms of Goa and/or Bugis became their patrons and protectors. According to the "Princess from a bamboo" myth summarized above (and regarded literally as history), the king married a mysterious Bajo lady, therefore the local Goa or Bugis dynasty has Bajo blood in its veins, thus the Bajos should not be considered as strangers.

\section{B. 'Push' or 'pull' migration factor?}

The cause of every documented human migration may be sketched using the 'push \& pull' factors, known as Lee's laws, see Lee [14]. A migration may be triggered by a natural disaster (flood, drought, volcano eruption...) or other 'push factors' (bad crops, hunger, war, low social status...) while 'pull factors' include the quest for economic opportunities, safety, freedom, etc. in the new location where migrants settle.

Considering the motivation of migrants, there is usually a mix of 'push' and 'pull' factors, for instance moving from rural to urban areas within the same country, or since a few years migrating from Middle East and Africa to Europe. For young rural Indonesians moving from Central Java to Jakarta or to Kalimantan for instance, the 'pull' factor is dominant (jobs, better income, wider opportunities). The migration is indeed often temporary, until retirement. On the other hand, considering Middle East or African migrants (mostly young men who take excessive risks in crossing Mediterranean Sea to reach Europe, where they will endure a miserable life) the 'push' factor is decisive: fleeing war in Middle East, or in Western Africa escaping family bullying and low expectations of getting a social status and finding a spouse, especially if polygamy is prevalent. Surprisingly, poverty is not the main factor, as disclosed by a recent survey; many male teenagers migrants left their families in Western Africa without previous notice.

Coming back to the Sama-Bajau fate, nobody knows when their migration started, if this migration was progressive or at once, why it happened, and of course where they lived before this dramatic event. The only things we can assert is that it happened, because today's linguistic and cultural data show that in olden times they had one and only homeland.

Of course, no historical documents, no archaeological clues are available to help us answering this question. Oral tradition is by nature doubtful, but if we consider the SamaBajau origin myths as a whole, regardless of the variations in the scenarios and characters, it appears that the cause of their migration is always described as a 'push' factor. The common feature is that they fled their homeland, not that they ventured overseas seeking new resources. None of the myths mentions any attractive commodity they may have coveted across the seas. Moreover, the cause which 'pushed' them away seems linked to a political power, forcing their ancestors to flee by sea. This powerful and threatening entity may be concealed under metaphors, like a giant skate fish towing the boats, or the egg yolk wave scattering them offshore. On the other hand, the central female character (Bajo princess and/or wife of a local ruler) represents the weaken Bajo people who search for alliance, protection, and depend on patron-clients good relations (this was clearly the case between Bajo and Bugis sea traders).

It is impossible to speculate furthermore about the cause of the initial Sama-Bajau migration; however, none of the myths evokes a return to the homeland, or any remaining links (through family or trade ties) with their homeland. Surprisingly, no nostalgia about this place of origin is reflected in these myths, the exact opposite of Promised Land memory in another displaced population, the Jews. The Bajo homeland has no name, and cannot even be linked to any of the wide islands of Southeast Asia. This sharp break leads to believe that the initial Bajo migration happened rather fast, not step by step. And probably not as peacefully as proposed by Blust [15]. Moreover, in the Bajo oral tradition, or in informal discussions with Bajo elders, I never noticed any collective hope of coming "back home", or any nostalgia for a supposed "golden age" in their forgotten homeland. Is this because of a considerable distance in time, or because they never had any hope of recovering their land, or in order to alleviate the collective trauma of being banished? We will probably never know.

Nothing is said about Bajo people who, for some reason, did not leave their homeland. The myths assume all the Bajos went at sea, and nobody stayed in the homeland. We should not suppose that only the Bajo men are sailors; those who were nomads used to sail in whole families, and according to many testimonies, until the $20^{\text {th }}$ century, Bajo women were perfectly able to steer a boat. Today no Bajo community 
claims they are still living at their original location. If some Sama-Bajau stayed behind, they have also forgotten this dramatic event, and are probably absorbed by other ethnic groups, like is now the case of the former Bajo villages in South Sulawesi (around Makassar), totally merged in the Bugis community, even if some elders still understand Bajo language.

In the literature on Sama-Bajau languages (SB), focusing on the Sulu archipelago, it is assumed that the Sama-Bajau settled there at the first stage of their migration, then centuries later sailed southwards to settle around Sulawesi and other places. It seems odd: if a group of person flee an immediate danger, why should they seek refuge altogether in one and only location (Sulu), rather than scatter here and there? We will return to this issue in part 3.

In sum, if we consider the common features of SamaBajau origin myths, it appears that their initial migration was caused by a powerful foreign entity, forcing them away by sea and may be violent means. The Sama-Bajau did not look for economic resources overseas, they had to flee their still unidentified homeland, and this event was sudden and abrupt. The myths implicitely recount that no one remained in the country, whereas no hope of return is evoked.

\section{RECENT GENOMIC DATA ABOUT THE INDONESIAN BAJO PEOPLE}

Since a few years, I collaborate with a team of geneticists, including researchers from Toulouse University (France) and Eijkman Institute (Indonesia). In the scope of this stimulating cooperation, their aim was to find out if there were specific genetic markers within the Indonesian Bajo community members, then to search for the same markers in other ethnic groups in Southeast Asia. Meanwhile, ideally, I would have found consistent linguistic data. If a particular ethnic group shares with the Bajo some genomic features, and specific language features as well, then we could argue that they had the same ancestors. The ethnic group never involved in maritime migration would then been considered as the descendants of "those who remained behind" when the initial Sama-Bajau migration happened. Or maybe their "cousins", who were close (geographically, genetically and culturally) to the Sama-Bajau before they had to leave.

A perfect coherence between genomics and linguistics findings would be a ideal outline, but three main obstacles arise. Collecting sample from Bajo volunteers in some communities was authorized and supported by the Indonesian government, but this kind of survey is still impossible in the Sulu, due to civil strife and armed conflict. Genomic data from Malaysia is available, but does not focus specifically the 'Bajau' ethnic group in Sabah. Our samples collection was bound to Indonesia; however, in North Kalimantan, we met volunteers who recently settled in Maratua island, having fled unrest and threats in Central and Western Sulu.

As will be argued below, the initial Sama-Bajau migration (when they were banished or forced to leave their homeland) took place around the $11^{\text {th }}$ centuries, if not earlier. If we find somewhere a community outside the SB diaspora, but which "matches" with our Bajo genomic and language data, it does not prove that their current location fits into the SB homeland: since a thousand years, they may have moved too, by land if not by sea.

Last caveat, the Bajo community is very open to intermarriages with individuals from other ethnic groups. Many of my Bajo informants around the Flores Sea and Makassar Strait had a grandparent or a parent from another ethnic group. For instance, in the tiny island of Sapeken (Kangean archipelago, north to Bali), marriages with Mandar, Bugis, Makassar, Madura, even Chinese (before the 1930s) are usual. Then the Bagai (strangers) are easily assimilated into the local majority of Sama. We were aware that the genomic data would reflect a high degree of admixture with other ethnic groups - and it did.

In Kusuma et al. [2] article "The last sea nomads of the Indonesian archipelago: genomic origins and dispersal", we report genome-wide SNP analyses on 73 Bajo individuals from three communities across Indonesia - Derawan of Northeast Borneo, Kotabaru of Pulau Laut in Southeast Borneo and Kendari in Southeast Sulawesi. Readers interested in the methodology and detailed resutlts of this study are advised to read the full paper; here I will only rush into its conclusions.

Firstly, the "out of Johor" origin recounted in some myths can be ruled out. No particular genomic features links the Indonesian Bajos to Peninsular Malays. "All Bajo individuals fall within the Island Southeast Asia cluster, specifically with other Indonesian groups. As before, all three Bajo communities still form their own clusters with limited overlap. Most Bajo individuals lie close to populations from Sulawesi, such as the Bugis and Mandar. The Derawan Bajo cluster close to Philippine populations; the Kotabaru Bajo cluster close to Borneo populations; whereas the Kendari Bajo have connections with eastern Indonesia, such as Sumba and North Maluku, and with Papuans." [2].

Being "close" to neighbouring populations means that there were a lot of genetic admixture, resulting from intermarriages. These three Bajo communities (namely, Derawan, Kotabaru and Kendari) have even more genetic connections with their respective neighbours than between each others. It underlines that becoming Bajo is more a cultural move (getting assimilated into a Bajo community) than a strict matter of genomic ancestry.

The admixture with South Sulawesi is higher in Kendari and Kotabaru Bajo communities, and genetics analysis shows it happened multiple times, which means that intermarriages between Bajo and South Sulawesi individuals took place over several generations (and it still does). On the other hand, Derawan samples show much less influence of the South Sulawesi component: "the Bugis appears to be a surrogate population for the Derawan Bajo, in addition to Malay, Filipinos and Indians."[2] This figure fits well with the linguistic data I will present in part 3, and supports my hypothesis that following the initial migration, not all the exiles found refuge in the Sulu. Part of them settled and/or wandered in the Makassar Strait, mainly around South Sulawesi, i.e. much closer from their starting point. 
However, we came upon a complete mismatch between genetics and linguistics regarding the likely Bajo homeland. "Despite a complex genetic history involving creolization and multiple admixture events, the genomic data are suggestive of a single population origin for the Bajo, converging on Southern Sulawesi." [2]. I take an opposite view: the SB languages are more linked to South-Barito (South Kalimantan) languages, than to any other language in Southeast Asia. There are many loanwords from Bugis in Indonesian Bajo, but these are borrowings only. The core of SB and Bugis syntax and lexicon are clearly unrelated (although they belong to the West Malayo-Polynesian family, like the majority of languages of Indonesia). After discussions with my geneticist colleagues, we agreed that this discrepancy could not be resolved now: "The linguistic and genetic evidence are therefore in broad agreement regarding the timing of the Bajo dispersal along the east coast of Borneo, but point to quite different locations for its origin: Southern Sulawesi for the gene pool and Southeast Borneo for the languages."

To my opinion, the very strong Bugis genetic component among Indonesian Bajos (except 'Derawan') could result from repeated admixture, over several centuries, which in turn highlights South Sulawesi as the most probable territory of origin for the Bajos. This has not been totally ruled out by my geneticist fellows: "the presence of a Southern Sulawesi genetic background in all Bajo communities may also result from contact directly between these three sea trading groups."

Genomics can be incredibly precise at assessing the age of admixtures. I was puzzled by the date given for the oldest admixture between Kendari Bajos and South Sulawesi populations: "62 generations ago (1736 years ago, assuming a 28-year generation interval)"; this takes us far back in time, at the end of the $3^{\mathrm{d}}$ century $( \pm 280$ AD), when my own ancestors where subjects of the Roman Empire. This first admixture stage was composed of $90 \%$ South Sulawesi gene contribution and $10 \%$ of Papuan (a broad label, not limited to today's Papua province). This does not mean that the initial Bajo migration occurred so early; but it indicates that there were regular contacts between South Sulawesi and the Bajo homeland since the $3^{\mathrm{d}}$ century, at least.

The Kotabaru samples analysis provides important information as well: "one admixture event between Indian (5\%), Sulawesi Bugis (70\%) and Bornean Banjar (25\%) sources around 33 generations ago (925 years ago)."[2] This dating, $11^{\text {th }}-12^{\text {th }}$ century $( \pm 1100 \mathrm{AD})$, does not contradict the scenario proposed by Blust [15]: he assumes that the Bajo migration to Sulu occurred in the $9^{\text {th }}$ century, simultaneously with the main migration from South Kalimantan to Madagascar. Implicitly, Blust timeline would entail that the Sama-Bajau and Malagasy ancestors were displaced at the same period, by the same powerful authority, from the same region of South Kalimantan... and were related genetically and/or linguistically.

This genomics study also found that the period of Bajo admixture with Sulawesi Bugis lasted until the $14^{\text {th }}$ century, but I suppose that since then, intermarriages have occurred on a regular basis. Indeed, this seems very common today; this may be a new surge, following to the sedentarization of the last Bajo nomads around the 1980s in Sulawesi and their improving economic integration into modern Indonesia.

A detail is also worth to notice: the $5 \%$ Indian contribution into the admixture event spotted at the beginning of the $12^{\text {th }}$ century is consistent with the spreading of Hinduism, along with Malay influence over the Western and Southern coast of Kalimantan. A Malay community was established in an area called Banjar, on the shores of a large bay, now filled by the Barito delta sediments. At that time, the current location of Banjarmasin city was in the middle of the bay.

The history of slavery, still underestimated in Southeast Asia, may also have impacted the genetic flows. Warren [16] shows that Sama-Bajau people were often the victims, and sometimes the perpetrators (esp. from Balangingi island, Sulu) of piracy. The usual pirates' bounty comprised men, women and children, abducted then sold, until the European colonial powers (after having been important buyers of slaves in the $17^{\text {th }}-18^{\text {th }}$ centuries), eradicated piracy, and subsequently slavery, in the second half of $19^{\text {th }}$ century. Warren [16] underlines that intermarriages between slaves and their masters or other Sulu people were frequent, and after one or two generations, the slaves' children were assimilated in the local community. The Sulu pirates Ilanun and Balangingi had a network of safe harbours, including over Makassar Strait, for instance Toli Toli and Dampelas (Sulawesi), Tunku and Berau (Eastern Borneo coast). That we can find Bajo communities in all these places today is perhaps no coincidence.

Finally, genomics can determine if an admixture event was balanced or not between men and women. Interestingly, a sex bias pattern appears in these Bajo admixture events: the female gene flow is lower, which means that the gene contribution into the Bajo community was brought by more men than women. The same bias has been observed for other sea nomad populations, like the Moken in Thailand and Myanmar. It may correspond to a weaker social and political position, compared to dominant local ethnic groups, for instance the Bugis, the Mandar, the Banjar... We should take myths more seriously: a Bajo lady or princess marries a local ruler, not the other way round.

\section{LINGUISTIC DATA: A NEW MAPPING OF INDONESIAN BAJO LANGUAGE}

The Sama-Bajau (SB) language family comprises a dozen of languages, including Indonesian Bajo(s). Some are mutually intelligible (for instance in the Sulus) and could have been described as a dialect chain. Indonesia is supposed to host one and only of SB languages, labelled Indonesian Bajo, a view that I will challenge. Pallesen [17] has shown that in Sulu archipelago (spanning between Mindanao and Sabah) the Sama-Bajau were the first settlers, circ. 9th century AD. They were then subdued by the Tausug from Mindanao, and mutual borrowings of vocabulary occurred between Tausug and SB. However, Pallesen notes that SB is not a Philippine-type language, therefore the Sama-Bajau must have originated from an unknown region of Indonesia. Pallesen believes that much later, from the $14^{\text {th }}$ century onwards, some SB groups settled westwards in Sabah and southwards along the coasts of Sulawesi, and later until the Eastern Lesser Sunda islands. In 
my view, Pallesen's proposed stages and dating of the Bajo arrival in Indonesia is not exact. But at the time of his fieldwork, he had no indication about the Sama-Bajau territory of origin.

Blust [15] convincingly shows that SB shares lexical innovations with South Barito languages (Southeast Kalimantan). He proposes the following scenario: around 800 $\mathrm{AD}$, an inland population from South Barito was required by the Sriwijaya empire to become freight shippers through the Strait of Makassar, until South China. An obvious stopover on this route was the Sulu archipelago, where the Sama-Bajau would eventually settle. For the subsequent stages of the Sama-Bajau migration, he believes that Pallesen stages apply. This scenario can be summarized as follows:

- \pm 800 SB leave South Kalimantan northwards to the Sulu and West Mindanao (South Philippines)

- \pm 1300 Some SB groups leave Sulu to Sabah, Sulawesi, Makassar strait.

- After \pm 1300 the Tausug from Mindanao invade the Sulu and subdue the SB. Vocabulary exchanges between Sulu SB and Tausug.

- The Sulawesi Bajo settle progressively southwards, until Lesser Sunda Islands.

I gathered lexical and grammatical data in various Bajo communities in Indonesia, and crosschecked it with the available documentation on SB (mainly from the Philippines and Malaysia, because Indonesian Bajo is much less documented). I noticed that there is not one and only SB language in Indonesia, as stated by Pallesen [17], Akamine [18], Lewis et al. [19], but at least two: one around South Sulawesi and Lesser Sunda Islands that I call 'Flores Sea Bajo', and another SB language, clearly related to Central and West Sulu Sama, spoken on Kalimantan East Coast, north from the Cape Mangkalihat (and including Derawan), and on the north coast of Sulawesi as well, across from the Sulu. In addition, the Bajo language spoken from South Kalimantan (Kotabaru) up to Cape Mangkalihat is either a dialect of Flores Sea Bajo or a distinct language among the SB family. Place lacks in this article to discuss this typological issues.

SB languages display a large number of Malay loanwords. Malay linguistic influence does not mean necessarily a Sriwijaya empire direct rule over South Kalimantan (which is not documented)[20]. Yet, Malay language and Hindu religion reached this region, as can be inferred from the rise of Banjar. Today's bahasa Banjar (Banjar language), a local lingua franca in the city of Banjarmasin and all around is southern Kalimantan, can be considered as a creole of Malay and local South Kalimantan languages. Adelaar [21] detected Malay loanwords in Malagasy, a language whose roots go back to the South Barito language family as well. This proves that the Malagasy pioneers had already borrowed Malay words before they sailed (or were carried by sailors) to Madagascar. Adelaar also identified very few South Sulawesi loanwords in Malagasy, which seems not so odd if we keep in mind the genomics findings: the Bajo ancestors intermarried with South Sulawesi (Bugis) as early as the $3^{\mathrm{d}}$ century AD. If the
Malagasy and Sama-Bajau ancestors were neighbours in South Barito, they may have set the same kind of relationships with South Sulawesi people.

There are more Malay loanwords in Sama Bajo languages than in Malagasy: up to $19 \%$ of the lexicon in Mapun, a South Philippines SB language, comes from Malay according to Blust [15]. This may reflect the 200 years gap between two events, namely the migration to Madagascar $( \pm 800$ AD) and the initial Bajo migration $( \pm 1100 \mathrm{AD}$, according to the admixture event involving a $70 \%$ Bugis gene inflow). Many Malay words were obviously borrowed by the Sama-Bajau before they were driven out of their homeland, while some other loanwords have been adopted centuries later; the fine phonological clues that support these distinct borrowing layers can be found in Blust [15]. Interestingly, the Sama-Bajau borrowed Malay words related to sea navigation, while they retained their own words to refer to parts of a boat. This feature points to a population living on a riverside or a delta; i.e. the Barito, a very large river, still a busy 'highway' to central Kalimantan.

Only the Flores Sea Bajo borrowed Bugis words, along with some South Celebes cultural traditions, while I did not find a single loanword from Tausug. For their part, the SB languages of the Philippines retain no trace of Bugis language, but have exchanged many words with Tausug (a displaced language from Mindanao). In sum, we have Flores Sea Bajo with Bugis loanwords but no Tausug loanwords; and Sulu SB languages with Tausug loanwords but no Bugis loanwords. Vocabulary borrowing usually happens when two communities are in close contact for quite a long period. Therefore, examining the linguistic and genomic data on today's Bajo people living around the Flores Sea, we have to admit that their ancestor never settled in the Sulu.

After being driven out their homeland (South Barito area, South Kalimantan), the Sama-Bajau did not follow altogether a linear route northwards to the Sulu (1500 km away), then five centuries later, back southwards. If people have to flee a serious danger, like war or miserable slavery, they will probably run (in this case, sail) in any direction to save their lives and preserve their freedom. They don't care about staying altogether and settling at the same refuge location. This is what the SB myths tell us, if we dare to interpret the symbols and metaphors: a powerful foreign authority forced them to leave their homeland and they subsequently scattered until today's diaspora. The peaceful scenario proposed by Blust seems more speculative: firstly, because the Sriwijaya empire was obviously master of the seas, and was probably not short of seamen staff to the point of teaching how to sail to the Barito river people and offering them professional opportunities as cargo carriers and traders. Secondly, when people engage freely in long distance trading, they retain their main harbour as an operating base, coming and going, but keeping their homeland in mind. This is what other Indonesian maritime-oriented ethnic groups did later, i.e. the Minangkabau and, again, the Bugis.

Today, no 'SB-like' language can be positively identified in the South Barito region; it would be ideal to come upon a witness language there and conclude that "these speakers are 
the descendants of the Sama-Bajau who remained in the country". However, there are some common lexical innovations (that is, words that do not reflect an Austronesian etymon, and are used only in this area). Blust [15] found that "There are about two dozen apparent innovations that are known only in SB and Barito languages, or only in these languages and one or two others. Some of these are lexical, and may be common innovations, while others involve irregular sound changes in the SB languages that point to early borrowing." I found about 20 additional words. Altogether, 45 shared lexical innovations seem a poor harvest, but sufficient to argue that it is not due to chance. Proto-Sama-Bajau was obviously related to the South-Barito cluster of languages, but is not the mother-language of any of the languages still spoken today in South Kalimantan.

\section{CONCLUSION}

In sum, I propose the following timeline leading to today's Sama-Bajau diaspora:

- End of the $3^{\mathrm{d}}$ century : related ethnic groups live in the South Barito region. A least one of these groups, the Sama-Bajau, have trade and/or cultural links with South Sulawesi, leading to intermarriages (Bugis admixture initial event).

- The Sama-Bajau were initally river or delta dwellers (i.e. Barito river), but progressively shift to travelling by sea. It seems that sea shipbuilding and navigation technology is borrowed from the Malays.

- \pm 1100 The Sama-Bajau leave their homeland (Barito river / bay / delta), South Kalimantan, under the pressure of a foreign power. Apparently, no one remained in the country, or those who were left behind merged with other ethnic groups.

- Part of the exiles settle in the Sulu archipelago. Other groups (i.e. the Bajo) find refuge closer from South Kalimantan, on the shores of Makassar Strait, and especially in South Sulawesi. In both clusters, sea nomadism develops, but is not the only way of life.

- \pm 1300 The Sulu Sama-Bajau are subdued by the Tausug from Mindanao. Sulu SB languages diversify and borrow many words from Tausug (and vice-versa).

- \pm 1500 From the Makassar Strait, the Bajo develop long distance trading, as far as Malacca, Maluku, probably Southern China. Many of them specialize in gathering marine commodities for their Bugis patrons.

- \pm 1600 The Bajo begin to settle in small hamlets around Sulawesi in the anticlockwise direction (Boné bay, Muna, Buton, Kendari, Banggai, Tomini bay...) and to Lesser Sunda Islands and Maluku. Some Sulu SB begin to settle in Sabah, on North Kalimantan and ashore the North coast of Sulawesi.

- \pm 1700 Following the fall of Goa-Makassar to the Dutch VOC (1666), South-Sulawesi Bajos shift to the authority of Boné-Bugis. They convert to Islam. During the colonial period, the Bajo and Bugis long distance trade shrinks. Eventually, the Bajo will be limited to fishing and local trading of marine commodities.

- 1750-1900 The Bajos, like other coastal dwellers, are often victims of pirates' raids, on the sea or ashore. Some others (esp. Balangingi island, Sulu) engage into piracy, selling captives as slaves.

- 1970s most of the sea nomads sedentarize, often under pressure of their respective governments. Today, almost all of the Indonesian Bajos are fishermen, fish wholesalers, or seaweed farmers. Their Sulu cousins are entangled in the violent conflict in the South Philippines.

The important finding is that, from the South Barito homeland, the Sama-Bajau exiles did not find refuge altogether $1500 \mathrm{~km}$ northwards in the Sulu and West Mindanao (South Philippines), then stayed there for centuries before some of them sailed back south to Makassar Strait and South Sulawesi. In my view, shortly after their eviction from their homeland, they split up in two clusters; one settled in the Sulu and West Mindanao area, the other one ashore Makassar Strait, mainly on South Sulawesi coast. These two clusters had few relations and lost touch. Their languages (about 8 Sulu SB languages on the one hand, Flores Sea Bajo on the other hand) are not mutually intelligible now, although they clearly belong to the same SB language family.

This team research combining genomics and linguistics has advanced the understanding of the Sama-Bajau diaspora history. The genetic admixtures dating roughly matches with the stages proposed by the linguists. However, there is still a discrepancy: genetics tells that the Sama-Bajau originated from South Sulawesi (broadly speaking, the Bugis area today). For their part, the linguists believe that the forgotten homeland of the Sama-Bajau was located in South Kalimantan, most probably on the banks of the Barito river. Both cannot be true, therefore additional surveys and more transdisciplinary collaboration is needed to solve this question.

\section{REFERENCES}

[1] Pirès, T., Suma Oriental: An Account of the East from the Red Sea to Japan, written in Melaka 1512-1515, ed. T.b.A. Cortesão. 1512-1515 (Ed.1944), London: Hakluyt Society.

[2] Kusuma, P.; Brucato, N; Cox M.; Letellier T., Manan, A.; Nuraini, C. Grangé, P.; Sudoyo, H.; Ricaut, F-X., "The last sea nomads of the Indonesian archipelago: genomic origins and dispersal" Eur J Hum Genet. 2017. http://www.nature.com/ejhg/journal/v25/n8/full/ ejhg201788a.htm

[3] Lapian, A.B., Orang laut, Bajak laut, Raja laut - Sejarah Kawasan Laut Sulawesi abad XIX. 2009, Jakarta: Komunitas Bambu. 282.

[4] Zacot, F.-R., Peuple nomade de la mer - les Badjos d'Indonésie. 2002, Paris: Maisonneuve \& Larose. 343

[5] Nagatsu, K., The Sama-Bajau in and around Sulawesi: Basic Data on Their Population and Ditribution of the Villages, S.A. Studies, Editor. 2007, Kyoto University \& Universitas Hasanuddin.

[6] Stacey, N., Boats to burn: Bajo fishing activity in the Australian fishing zone. Asia-Pacific Environment Monograph 2. 2007: ANU E Press.

[7] Nuraini, C., Indonesian Bajo History and Narratives: the Iko-Iko Epic Songs, in Oceans of Sounds, B. ABELS, Editor. 2012, Georg Olms Verlag: Hildesheim. p. 141-165. 
[8] Sather, C., The Bajau Laut - adaptation, history, and fate in a maritime fishing society of South-Eastern Sabah. 1997, Oxford: Oxford University Press. 359.

[9] Liebner, H., Four oral versions of a story about the origin of the Bajo people of southern Selayar, in Living through histories: culture, history and social life in South Sulawesi, K. ROBINSON and M. PAENI, Editors. 1998, Research School of Pacific and Asian Studies, Australian National University: Canberra. p. 19-23.

[10] Liebner, H., A Princess Adrift: Bajau Origin Stories, in Unknown conference (PPT presentation). 2012: Tanjung Pinang.

[11] Pelras, C., "Notes sur quelques populations aquatiques de 1'Archipel nousantarien." Archipel. (3): p. 133-168, 1972.

[12] Nimmo H, A., The Sea People of Sulu. Studies in Social and Economic Change, ed. L. BROOM. 1972, SAN FRANCISCO: Handler Publishing Company. 104.

[13] Hoogervorst, T., "Ethnicity and aquatic lifestyles: exploring Southeast Asia's past and present landscapes." Water Hist. 4: p. 245-265, 2012.

[14] Lee, E.S., “A Theory of Migration.” Demography. 3(1): p. 47-57, 1966.

[15] Blust, R., "The Linguistic Lineage of Sama-Bajaw." Studies in Philippine Languages and Cultures. 15: p. 210, 2007.
[16] Warren, J.F., The Sulu Zone 1768-1898 - The Dynamics of External Trade, Slavery, and Ethnicity in the Transformation of a Southeast Asian Maritime State. 2007, Singapore: NUS Press. 390.

[17] Pallesen, K., Culture contact and Language Convergence. 1985, Manila: Linguistic Society of the Philippines.

[18] Akamine, J., Sama (Bajau), in The Austronesian languages of Asia and Madagascar, A. ADELAAR and N.P. HIMMELMANN, Editors. 2005, Routledge: New York. p. 377-396.

[19] Lewis, M.P., G.F. SIMONS, and C.D.E. FENNING, Ethnologue: Languages of the world, Nineteenth edition. 2016, SIL International: Dallas.

[20] Degroot, V., Personal Communication. 2017.

[21] Adelaar, A., Towards an integrated Theory about the Indonesian Migrations to Madagascar, in Ancient Human Migrations - A Multidisciplinary Approach, P.N. Peregrine, I. Peiro, and M. Feldman, Editors. 2009, The University of Utah Press: Salt Lake City. 